\title{
PSYCHOLOGICAL PECULIARITIES OF FOREIGN LANGUAGE COMPETENCE FORMATION IN THE MONOLOGIC SPEECH OF FUTURE PHILOLOGISTS
}

\section{Hanna Bahrii}

\section{INTRODUCTION}

In the context of integration into a common educational space with the countries of the European Union, the language skills of the Ukrainian university graduates must also meet the common European requirements for proficiency in non-native languages. These include the ability to freely participate in any conversation and discussion, having a variety of idiomatic and colloquial means of speech.

The problem of foreign language competence formation in monologue speech remains relevant, since it needs consideration in the context of a competency-based approach that will allow it to be reconciled with others language and language competences - components of foreign language communicative competence, the formation of which is the purpose of learning foreign languages and cultures in educational institutions.

The problem of teaching monologue speech has a leading place in the scientific and methodological literature. The problem under study is considered by many methodologists such as B. Skalkin ${ }^{1}$, G. Rogova ${ }^{2}$, I. Zimnaya ${ }^{3}$, S. Passov ${ }^{4}$, M. Bukharkina ${ }^{5}$ and many others.

Psychological, pedagogical and methodological literature covers the experience of methodological organization of teaching monologic speech: a number of domestic and foreign studies devoted to the structure of speaking, general theoretical issues of teaching monologue (such as linguistic) and

${ }^{1}$ Skalkin V. L. (1983). Obucheniye monologicheskomu vyskazyvaniyu: posobiye [dlya uchiteley]. [Teaching monologic utterance: a manual [for teachers], (p. 55) [in Russian].

2 Rogova G.V., Rabinovich F.M., Sakharova T.Ye. (2000). Metodika obucheniya inostrannomu yazyku $v$ sredney shkole [Methods of teaching a foreign language in high school], (p. 49 - 50) [in Russian].

${ }^{3}$ Zimnyaya I.A. (2001). Lingvopsikhologiya rechevoy deyatel'nosti [Linguopsychology of speech activity], (p. 113). [in Russian].

${ }^{4}$ Passov S.I. (1988). Urok inostrannogo yazyka v sredney shkole [Foreign language lesson in high school], (p. 51-52) [in Russian].

5 Bukharkina M. YU. (2005). Metod proyektov v obuchenii angliyskomu yazyku [The project method in teaching English]. Inostrannyye yazyki $v$ shkole [Foreign languages at school], 3. p. $24-28$ [in Russian]. 
others, functional types of monological statements, various aspects of the methodology of monologue speech learning a foreign language in high school. Achieving a high level of development of a student of oral English ensures the readiness of future specialists to make real use of the acquired knowledge and skills in their professional activity. Therefore, proficiency in English is the key to the growth of professional skills of a modern specialist, in particular a future interpreter.

\section{The Peculiarities of Monologue Speech}

Scientists identify two types of oral activity: dialogue and monologue. The ability to build monologues is more complex than the ability to engage in dialogue. According to V. Skalkin ${ }^{6}$, monologue speech is contextual, unlike dialogue, which is most closely dependent on the situation. In dialogic language, the transmission of information is directed in two or more directions, each communicator's periods of speech activity are changed by periods of perception and processing of information, which contributes to facilitating communication.

Monologue speech, unlike dialogue speech, is characterized by the activity of only one communicator, which means "planning and programming not only one utterance or sentence, as, for example, in dialogue, but also the whole message". Note that monologue speech is a process of long, consistent, coherent presentation of a system of thought. Monologue language, which is the oral utterance of one person for the purpose of communicating information, influencing or inciting an action that has been considered earlier.

V. Skalkin understands the monologue speech as the process of communicatively motivated, logical, consistent and difficult, quite complete and correct in speaking verbally.

According to S. Passov, in the scientific context, the concept of "monologue speech"7 does not exist. He explains this contradiction by saying that when we say that no monologue exists, we mean that any communication (and we teach it) is dialogical in nature. There are always two parties involved: not only the speaker, but the listener. In general, this means that there are no statements that would had no orientation, purposefulness, there was no speaking in the void.

${ }^{6}$ Skalkin V.L. (1989). Obucheniye dialogicheskoy rechi [Teaching dialogic speech.], (p. 8-10) [in Russian].

${ }^{7}$ Passov S.I. (1988). Urok inostrannogo yazyka v sredney shkole [Foreign language lesson in high school], (p. 51-52) [in Russian] 
Scientist A. Alkhazishvili believes that monologue speech is of great importance in the context of a meaningful point of view of oral language ${ }^{8}$. $\mathrm{He}$ argues that monologue speech is less complex in terms of the use of speech samples than dialog.

Monologue speech has great compositional complexity, requires completeness of thought, adherence to grammatical rules, strict logic and consistency in teaching the content of the monologue. Therefore, teaching monologue speech is a great challenge for students.

Considering the studied and own experience of teaching a foreign language, we can distinguish the following difficulties that students face when working on a monologue in class:

- inability to work on different types of texts, which present the following types of information (story, description, reasoning);

- mastery of the means of expression of subject-emotional attitude to the object of expression;

- ignoring one of the principles of the communicant social portrait of the listener, the age of the addressee, his awareness of the issue, needs and interests;

- ignorance that listeners are at the same time spectators, so when speaking it is necessary to think not only about the content, but also how to speak;

- ignorance that speaking one's own monologue is productive but not reproductive;

- lack of integrity, coherence, reasoning and expression.

A number of scientists in the methodology highlights the following characteristics of monologue:

1) continuity (allows the speaker to express his or her thoughts fully), accessibility and clarity;

2) consistency and logic;

3) completeness and coherence of presentation of thoughts, development;

4) fullness of sentences, unidirectionality.

From a linguistic point of view, monologue is characterized by the full complexity of sentences and, as a rule, by a comprehensive presentation of thoughts ${ }^{9}$.

\footnotetext{
${ }^{8}$ Alkhazishvili A. A. (2000). Osnovy ovladeniya ustnoy inostrannoy rech'yu [Fundamentals of mastering oral foreign speech], p.72-73 [in Russian]

9 Symonenko T. V. (2006). Teoriia $i$ praktyka formuvannya profesiinoi movnokomunikatyvnoi kompetentsii studentiv filolohichnykh fakultetiv. [Theory and practice of formation of professional linguistic competence of students of philological faculties.], (p. 38-40) [in Ukrainian]
} 
According to the communicative purpose we can distinguish the following monological statements:

1. by the purpose of expression:

- monologue message;

- monologue-description;

- monologue-reasoning;

- a monologue-story;

- a monologue-persuasion.

2. by degree of readiness:

- prepared monologic language;

- unprepared monologue (own judgment, without support).

The substantive side of monologue speech must be combined with the expressive side that is created through linguistic means (use of words, phrases) and non-linguistic communicative means (mimics, gestures, intonations, pauses systems).

An important role in the teaching of monologue speech should be given to the creation of motives and conditions under which students show cognitive activity and feel the desire to use their knowledge, skills and abilities. But stimulating interest and maintaining high motivation in learning English is one of the problems of high school. P. Jacobson attributes such motivation to the motivation inherent in the process of activity itself ${ }^{10}$.

Thus, techniques, exercises, organization, creation of certain conditions for the organization of language exercises can influence the power of motivation. Therefore, it is important for the teacher to apply the optimal techniques of teaching monologue in English classes. Note that admission is specific actions and operations of the teacher, the purpose of which is to convey knowledge, to form skills and stimulate students' learning activities to solve problems in the learning process.

To overcome the above difficulties that students - future philologists may encounter in preparing a monologue, the teacher should master a variety of methodological techniques of teaching monologue.

One of the techniques of teaching monologue speech is the Project. I. Sokol notes that "the project is an implementation of self-planned work in which the monologue is organically combined in an intellectual-emotional context with other activities" $" 11$.

\footnotetext{
${ }^{10}$ Yakobson P.M. (1969). Problema motivatsii v psikhologii povedeniya cheloveka. [The problem of motivation in the psychology of human behavior] [in Russian].

11 Sokol I.A. (2008). Proyekt kak metod realizatsii kommunikativnogo podkhoda $v$ obuchenii inostrannomu yazyku [Project as a method of implementing a communicative approach in teaching a foreign language]. Inostrannyye yazyki $v$ shkole. [Foreign languages at school], 1, (p. 16-21) [in Russian].
} 
Many researchers note that the monologue is a form of oral communication that has a three-level structure. This structure includes: the first stimulating motivational phase, in which the speaker knows only the general subject or topic of the utterance and form of interaction with the listener; the second analytic-synthetic phase is the phase of thought formation by the means of language, characterized by logical consistency and syntactic correctness of speech expression; and the final third is the executive phase, which is responsible for the pronunciation and intonation of the monologue.

Bukharkina notes that the phases of the monologue and the stages of work on the project of expression are similar ${ }^{12}$. The project activity includes the following steps problem selection and formulation of a specific project theme; collection and processing of information; summarizing and presenting a new project.

Therefore, it is possible to outline the stages of work on the project as receiving the training of monologue. The first stage is the beginning and planning. The goal of this phase is that the teacher motivates students future philologists to achieve the result and explains the purpose. The second stage of the work is the formation and formulation of the monologue. At this stage that students encounter difficulties: what and how to pronounce in English, since they do not yet have the structure of expression. To do this, the teacher must be offered students visual support that helps to build a monologue (introduction, main part, conclusion) and focus efforts on mastering active vocabulary on the topic.

Another method of teaching monologue speech is Presentation - a presentation or verbal expression on a specific problem ${ }^{13}$. The features of this technique are depth of content, comprehensive expression, a clear organization, characterized by linguistic and information complexity and has an effective impact on the audience. For example, a presentation may reflect the results of a problem, or summarize research findings.

The goals of the presentation include: a detailed presentation of information, expression and presentation of one's vision, argumentation of points of view, beliefs.

Oral speech implies that the learner is able to interact with the audience. Presentation has the following structure: 1) a short presentation containing

${ }^{12}$ Bukharkina M.YU. (2005). Metod proyektov v obuchenii angliyskomu yazyku [The project method in teaching English]. Inostrannyye yazyki $v$ shkole [Foreign languages at school], 3. p. 24 - 28 [in Russian].

13 Bogdanova S. S. (1988). Logiko-kommunikativnyye programmy pri obuchenii monologicheskomu vyskazyvaniyu [Logic-communicative programs in teaching monologic utterance], 5, p. 35-43 [in Russian] 
the main idea and goal setting; 2) detailed presentation of information, development of the main idea, its justification, clarification; 3) arguments and conclusions; 4) engaging in discussion.

Communicative techniques for teaching monologue speech of students future philologists can also be referred to as the techniques of creating semantic associations (word associations): brainstorming, mind-mapping, the main task of which is generating ideas. In the course of their implementation, students are interested in finding bright, original, metaphorical analogies. A semantic association may be motivated by a keyword or concept, theme, or visual image that is associated with a broad semantic notion.

Brainstorming and mind-mapping allow students - future philologists to stimulate speech and thinking activity, actualize the speech experience, enrich the vocabulary. For example, when drafting a semantic map, students are encouraged to construct their own monologue statements that will be addressed to a specific audience.

\section{Factors of Formation of Students-Philologists Competence in Monologic Speech}

Increasing scientific interest in the humanization of higher education is due to many factors ${ }^{14}$. That is why the current stage of education development is characterized by the desire to reveal the theoretical foundations of its humanization, to systematically and organically integrate the formation of linguistic cultural competence in the process of professional formation of the personality of the future philologist.

In our opinion, communicative competence should be considered as a person's ability to understand and reproduce a foreign language not only at the level of phonological, lexico-grammatical knowledge and language skills, but also in accordance with the various goals and specifics of the communication situation.

We believe that from these points of view, it is not enough for speech communication to know only the language system at all its levels, to have rules for the generation of sentences designed according to grammatical norms, but it is also necessary to exercise its influence on the interlocutor in accordance with the task and situation of communication to use speech utterances.

${ }^{14}$ Tarnopolskyi O.B., Kozhushko S.P. (2008). Metodyka navchannya studentiv vyshchykh navchalnykh zakladiv pysma anhliyskoyu movoyu [Methods of teaching students of higher educational establishments writing in English], (p. 87-88) [in Ukrainian] 
Students - future philologists may not be ready for a monologue (unwilling to speak) or ashamed to speak, afraid to make a mistake, and thus criticize teachers and students. In this case, the teacher should remove the psychological barriers: to create a friendly atmosphere in the classroom, not to allow students to criticize sharply each other, to motivate students to produce monologues, interested in their topic, a problem that is familiar to them, known from their life experience.

Students - future philologists sometimes lack the vocabulary and speech tools to construct a monologue. To solve this problem, it is necessary to create a sufficient level of support for a meaningful, linguistic and speech plan. This means that development of monologue speech skills should be based on the already formed phonetic, lexical and grammatical skills within the suggested topic. Students should be able to use intonation and grammar correctly, logically design their speech through various means of communication $^{15}$. The substantive and linguistic value of the exercises is of great importance. The tasks offered to students should correspond to the real information stock of the students. Taking into account cross-curricular relationships can make it easier to solve the practical problems of mastering monologue. Different verbal and non-verbal supports can greatly help.

Sometimes a student cannot understand the speech task of creating a monologue. To overcome these difficulties, the teacher needs to know in advance what type of monologue he wants to get from the student, create a speech situation, clearly and concisely formulate the speech instruction, and prepare the necessary supports if necessary.

Consequently, we define communicative competence as an individual dynamic category that reflects the unity of language and personality.

Purposeful work on the formation of communicative competence was understood by us as a holistic process based on the coordination of its leading components: targeted, one that reflects the requirements of simultaneous participation of all students in the performance of individual tasks; meaningful, based on the selection of tasks that contribute to the successful formation of communicative competence; technological, defining conditions, methods and means of forming communicative competence; evaluation and effectiveness, based on the design of diagnostic methods for determining the formation of communicative competence.

15 Levchyk N. S., (2015). Formuvannya anhlomovnoyi audytyvnoyi kompetentnosti pershokursnykiv - maybutnikh uchyteliv anhliys'koyi movy [Formation of English-speaking auditory competence of freshmen - future English teachers]. Seriya: Pedahohichna: nauk. zapysky. Linhvodydaktyka [Series: Pedagogical: scientific notes. Linguistics.], 3. (p. 80-86) [in Ukrainian] 
On the basis of the identified leading components of students' communicative competence, we have developed a communicative and project-based method of forming the communicative competence of students of philological specialties.

The purpose of the practical English language course for students of philological specialties is the purpose of forming communicative competence in English speaking ${ }^{16}$ (in oral and written forms with actualization on a professional component), that is, a practical vocational oriented mastery of students in English speech, reading, listening, writing).

In our opinion, special attention should be paid to the implementation of professional and socio-cultural components (development of reading skills, abstracting and annotation of texts in the specialty and country studies, monologic and dialogical expression in the professional field of communication), so students - future philologists should:

- read authentic English literature on a specialty and socio-cultural subjects for obtaining information and its use in the further professional activity;

- abstract and annotate scientific literature in the specialty;

- participate in professional communication in English;

- have a structure of the document science of the country of the language being studied.

When organizing the learning process in order to form the communicative competence of students-philologists, the teacher should take into account the following factors in the development of educational activities ${ }^{17}$ :

- teaching a short translation of the content of the read or heard text in English (Ukrainian), as well as the preparation of annotations and short essays should be carried out in the course of performing a number of special exercises;

- phonetics and grammar are presented not as a set of rules for study, but as a language material, in the process of working on which the student's language skills and abilities are formed;

- mastery of lexical material occurs in the course of work on the texts of textbooks, manuals, humanities and original literature in the specialty;

- reading texts at all levels of study use authentic, compositional, structural and content-complete, different in volume and linguistic saturation

${ }^{16}$ Tal'skova N.D. (2004). Teoriya obucheniya inostrannym yazykam [ Theory of teaching foreign languages], (p. 224 - 225) [in Russian]

${ }_{17}$ Hymes, D. (1972). Hymes D. (1972). On communicate competence: Sociolinguistics. Harmondsworth, Middlesex: Penguin Education, (pp. 269-293) 
at different stages of learning. The average volume of classroom reading is 200-300 pages;

- phonetic minimum implies correct articulation of sounds, adherence to reading of all punctuation marks by pauses of different lengths, use of three basic tones (falling, lifting, falling-lifting);

- the lexical minimum is 2500 lexical units ( 1 module -800 lexical units, including the school minimum; 2 - 1200; $3.4-500)$. Composition of vocabulary: common, social and humanitarian, general scientific, terms of the subject of the science under study;

- the grammatical minimum includes normative grammar, as well as grammatical phenomena characteristic of the subject of the science under study and grammatical phenomena that present difficulties in learning the language;

- at the initial stage of learning systematized and generalized knowledge of the language acquired in secondary school, a phonetic, grammatical and lexical basis for the student's further work on the language is laid. Attention is paid to mastering the sounds and basic types of intonation and development of spoken language skills; the basics of listening to the English text are laid and the skills of reading socio-political and professional literature (for some purpose of adaptation) are formed;

- in the process of achieving the practical goal, general, cognitive and educational tasks are also realized. Studying English as a cultural and social phenomenon should contribute to the formation of students of general culture, the deepening of general linguistic knowledge. Therefore, it is recommended to use $40 \%$ of all the text material in the field of national and social sciences and humanities;

- topics for the development of oral language skills should be related to the life of students, their hometown, significant dates, the countries of languages being studied, as well as topical issues of social and humanitarian life in Ukraine and in the English-speaking countries.

We should also take into account the complex psychological nature of monologue speech, which influences the success of mastering this type of speech activity. Thus, during a monologue, the speaker should perform complex tasks: 1) to remember everything he said to the other party; 2) to present as a whole his statement; 3 ) to retain in memory the keywords and phrases predicted by the content of future utterances; 4) to formulate the meaning of the phrase, which should be expressed at the moment; 5) to build sentences from programmed components; 6) to overcome the interference of the mother tongue, which hinders the construction of a foreign language utterance correct from a lexical and grammatical point of view; 7) to listen to 
own speech, to control its normativity, if necessary to correct parts of the phrase that have already been spoken ${ }^{18}$. Thus, monologue speech is, first and foremost, an increased workload for operational and long-term memory, thinking and speech mechanisms of the individual.

It is possible to teach students to build a program of their own monologue utterances, overcoming these difficulties, by means of advanced communicative tasks in which the ultimate goals are clearly formulated, and the utterances are limited by instructions, specially created supports, and intelligently selected language material necessary for the implementation of languages ${ }^{19}$. The success of teaching monologue speech also depends on the individual age characteristics of students, the presence of motives for learning, attention, interest, the level of mastery of students general and special educational skills in learning a foreign language, that is, the level of educational and strategic competence.

The development of students' oral monologue speech should be carried out with the help of a specific methodological system, including the organization of training, which would contribute to the successful formation of monologue speech. Factors that positively influence the learning process are favorable learning conditions, effective subsystem of exercises for teaching monologue, the presence and rational use of all necessary teaching aids, various and optimal forms of students' work in classes, the appropriate structure of foreign language lessons.

\section{Technology of Formation of Speech Competence of Future Philologists in the Process of Studying Professional Disciplines}

The analysis of the state of speech competence was updated the need to find ways to increase the effectiveness of future philologists stydying in the context of modern social and educational needs. Such an instrument, in our opinion, could be the technology of forming the speech competence of future philologists in the process of studying professional disciplines, which is based on a set of sound pedagogical conditions as the initial factors of the effectiveness of the process under study.

${ }^{18}$ Martynova R.Iu. (2013). English for social teachers: navch. posibnyk dlia studentiv pedahohichnykh universytetiv. Odesa : vydavets Bukaiev Vadym Viktorovych [in Ukrainian]

${ }_{19}$ Zadorozhna, I. P., (2012). Zadorozhna I. P. (2012). Teoretyko-metodychni zasady orhanizatsii samostiynoi roboty maybutnikh uchyteliv $z$ ovolodinnya anhlomovnoyu komunikatyvnoyu kompetentsiey. [Theoretical and methodological foundations of the organization of independent work of future teachers to master English-speaking communicative competence], (p. 482) [in Ukrainian] 
Technology in the scientific literature is considered as an algorithm of the organization educational process containing the goals, content and methods of achievement planned results ${ }^{20}$.

Interesting, in our opinion, is the difference between educational and pedagogical technologies, given the level of innovation. So is educational technology reflect strategies in education by predicting its further development, design and planning of the educational environment. Pedagogically technology reproduces the tactics of educational transformation through reflection models of educational and / or management processes. That is, we are designing pedagogical technology that demonstrates tactics realization of pedagogical conditions of speech competence formation future foreign language teachers in the course of study of professional disciplines.

There are two types of speech forming technologies competence ${ }^{21}$ :

1) cognitive-oriented, modeled from language to speech ", reflect the rational-logical way of mastering the language and include grammatical, analytical, comparative methods;

2) communicative-oriented, based on a "speech-to-speech" model, reflect a situational way of mastering a language through natural (or close to natural) communication situations.

We have developed a technology for the formation of speech competence of future philologists in the process of study of professional disciplines is a communicative-oriented, purposeful, systematic pedagogical activity to harmonize the goals, forms, content, methods and learning outcomes.

This understanding of the technology of speech competence formation defines its structure: target, organizational, content, process and result components.

In general, we consider the process of organizing the speech competence of future educators as creating the conditions for the development and implementation of technology, which will ensure coherence and interconnection between technological components. That is, theoretically and empirically substantiated pedagogical conditions, being realized in the process of studying professional disciplines, provide a rational structure of pedagogical influence and educational interaction ${ }^{22}$.

20 Canal M. (1983). From communicative competence to communicative language pedagogy. Language and Communication. (pp. 2-27).

21 Hymes, D. (1972). On communicate competence: Sociolinguistics. Harmondsworth, Middlesex : Penguin Education, (pp. 269-293).

${ }^{22}$ Leont'yev A.A. (2003). Yazyk, rech', rechevaya deyatel'nost' [Language, speech, speech activity], (p. 62-63) [in Russian]. 
Inferring psychological and pedagogical conditions into a separate component of technology reflects the procedural approach to its design and implementation, substantiating the forms of organization of the process of study of professional disciplines (according to the above conditions: monitoring, case study, dialog teaching, training and production practices).

In addition, when characterizing psychological and pedagogical conditions, we define the connection of each condition with theoretical approaches in pedagogy and psychology, which allows us to fulfill the necessary requirements for the technological process of formation of speech competence. Specifically, the requirements are: conceptualisation as a support for pedagogical theories, systematicity as ensuring the interconnection and integrity of pedagogical transformations, controllability and reproducibility due to the ability to control the organization of psychological conditions for the study of professional disciplines. The specified requirements meet the criteria of adaptability.

The process of mastering the foreign language knowledge and skills of monologue is accompanied by the development of communicative abilities of those who learn a foreign language. Communicative abilities to monologue speech are the social and communicative abilities of the individual, which ensure the effective implementation and management of communication in monologue form. The communicative abilities, on the one hand, are the result of the students' activity in monologue speech, and on the other hand, determine the success of its implementation. Communicative abilities for monologue speech are the following ${ }^{23}$ :

- intrinsic motivational readiness (desire) to speak, a sense of need to say something, the speaker's ability to understand what he or she wants to say, or external motivational readiness as a response to a verbal stimulus (an interlocutor's response to a question, that is, a speech caused by a situation communication);

- the ability to organize his monologue, structure and conclude it;

- the ability of the speaker to navigate the situation, ie the ability to receive and correctly understand signals from the listener / listeners and external circumstances of the situation, the ability to change their expressions and behavior in accordance with these signals in order to achieve the greatest adequacy and effectiveness of monologue speech in terms of purpose and purpose intentions;

${ }^{23}$ Kabardov M. K., Artsishevskaya Ye.V. (1996). Tipy yazykovykh i kommunikativnykh sposobnostey $i$ kompetentsiy. [Types of linguistic and communicative abilities and competencies.], 1. (p.34 - 49) [in Russian] 
- the ability to remember what has been said before by the speaker, thereby ensuring the coherence of speech, its logic, the ability to express an opinion, to find in the long-term memory the language forms of expression needed and to combine them into coherent sentences and coherent text based on random access memory;

- the ability to understand, reflect on the content of one's monologue (subconsciously, in standard situations and conditions) and its linguistic form (consciously and semi-consciously, in non-standard (problematic) situations and conditions), the ability in normal quiet speaking, to correct and change said directly in the speech process;

- the ability to formulate expressions that satisfy the linguistic norm and usages, including the requirements regarding the linguistic form of expressions that exist in a given linguistic and cultural community;

- ability to focus attention not only and not so much on linguistic rules and norms, but on rules and norms of communication and behavior in it; adequate;

- the ability to use paralinguistic means to make their language more

- the ability to express oneself through monologue speech due to the need for self-affirmation, intrinsic high motivation (the process of speaking is gratifying), the ability to express oneself by means of a foreign language being studied, to express one's own thoughts, views, emotions, attitude to what it is about interesting to convince the listener etc;

- the ability to self-evaluate what is said through controlling one's own utterances, to compare what was actually said, with what was intended to be said, and with what impact the said has on the listener;

- the ability to control emotions, to fully adequately assess what is said, so as not to cause (due to strong emotions) to disrupt communication or to achieve a result exactly opposite to what was planned, etc.

In addition, communicative abilities also include general abilities for monologue speech, including those developed on the material of the mother tongue that underlie the personality's ability to produce verbal expressions ${ }^{24}$. These are language/speech abilities: the students' well-developed psychic processes related to monologue speech activity (attention, operative and long-term memory, logical, analytical, imaginative thinking, imagination, fantasy, speech mechanisms of speech), as well as motives, needs, interests, directions, feelings and emotions, experience in outlook, activity, willingness to overcome difficulties, communication skills, desire for self-

${ }^{24}$ Vol'fovs'ka T. O. (2001). Komunikatyvna kompetentnist molodi yak odna z peredumov dosyahnennya zhyttyevyi mety [Communicative competence of youth as one of the prerequisites for achieving a life goal]. Shliakh osvity [Path of education], 3. (p. 13-16) [in Ukrainian] 
expression in monologue speech and other abilities for intercultural monologic communication (communication skills, tolerance ness, the ability to interact socially with students/partners in communication, culture, communication, ability to adequately communicate with people of different national cultures).

Exercises for the development of foreign language monologue can be divided into preparatory and language. With their help, specific for monologue speaking skills are produced. Preparatory exercises are aimed at learning the components of monologue speech: the formation of phrases and their combination in accordance with the logic of presentation. At the same time you need to be able to justify the correctness of your statements, including in your language elements of reasoning, argumentation, etc. Language exercises are aimed at developing skills to consistently reveal a topic, translate text, make a description, a message, a story.

Exercises for teaching prepared monologic language of philological orientation include: reproducing coherent statements; drawing up a situation or story; description of the drawing; reproduction of situations; legend; transfer of information in several phrases; drawing up a plan for a listening story; presentation of dialogues in monologue form and the like. Exercises for teaching unprepared monologue speech: inventing a title and its justification; a description of the painting not related to the topic under study; substantiation of own judgment or relation to facts; evaluation of what has been heard or read; expressing one's own opinion; comment and discussion ${ }^{25}$.

In the process of teaching a monolingual monologue, it is possible to distinguish three stages of formation of monologic skills ${ }^{26}$ : Stage I - to teach students to combine the speech patterns of the phrase level into one unity; Phase II - to teach students to build expressions beyond phrase level; Stage III - to teach students to create monological expressions of the textual level of different functional-semantic types of speech.

One of the most important features of the monologic speech of a translator of philological orientation is its situationality, in fact, the external circumstances in which the communication takes place: place, time, personality of the partner(s), social roles of the interlocutors, etc.

Due to the constant development of international relations, organization of business trips, exchange of specialists, as well as participation in various

${ }^{25}$ Rogova G. V., Rabinovich F. M., Sakharova T. Ye. (2000). Metodika obucheniya inostrannomu yazyku $v$ sredney shkole. [Methods of teaching a foreign language in high school], (p. 49 - 50) [in Russian]

${ }^{26}$ Skalkin V. L. (1983). Obucheniye monologicheskomu vyskazyvaniyu: posobiye [dlya uchiteley]. [Teaching monologic utterance: a manual [for teachers]] (p. 55). [in Russian] 
competitions, meetings, conferences, olympiads, our country needs specialists who have not only qualitative knowledge in their professional sphere, but also possess sufficient English language skills that are able to represent Ukraine abroad well ${ }^{27}$.

Therefore, language skills are part of the philologist's professional competence.

The issue of determining the specificity of English monologic language of philological orientation is relevant in view of the issue of increasing the language activity of students of philological specialties in the process of learning a foreign language by professional direction ${ }^{28} 29$. The effectiveness and efficiency of this type of speech is determined by the theme of the sociopedagogical text and its content. The specificity of the monologue speech of the philologist-translator depends on the situations that arise in professional activity or communication.

\section{SUMMARY}

The article is devoted to the study of the peculiarities of teaching monologue speech of students in English classes at universities. Theoretical analysis of the research problem suggests that monolingual monologic communication is possible provided that the subjects of foreign language communication speak the language as a means of communication. Level of the effectiveness of the communication process is conditioned by the level of formation of the subject's foreign-language monologic communicative competence.

Competence is the persistent willingness and ability of a person to engage in any activity with the knowledge of the case. In our case, such activity is the foreign language communication of students in the process of learning a foreign language. Hence the definition of foreign language communicative competence as an integrative formation of personality, which has a complex structure and acts as an interaction and interpenetration of linguistic, socio-cultural and communicative competences, the level of

\footnotetext{
${ }^{27}$ Zimnyaya I.A. (2001). Lingvopsikhologiya rechevoy deyatel'nosti [Linguopsychology of speech activity] (p. 113). [in Russian]

${ }^{28}$ Tarlakovskaya Ye.A. (2009). Obucheniye studentov lingvisticheskogo vuza sposobam realizatsii funktsii vozdeystviya monologicheskoy rechi [Teaching students of a linguistic university how to implement the function of the impact of monologic speech.], (p. 23-24) [in Russian]

29 Zadorozhna, I. P., (2012). Zadorozhna I. P. (2012). Teoretyko-metodychni zasady orhanizatsii samostiynoi roboty maybutnikh uchyteliv $z$ ovolodinnya anhlomovnoyu komunikatyvnoyu kompetentsiey. [Theoretical and methodological foundations of the organization of independent work of future teachers to master English-speaking communicative competence], (p. 482) [in Ukrainian]
} 
formation of which allows the future specialist to effectively perform a foreign language, and thus interpersonal communication.

Our study theoretically establishes more effective methods of teaching and forming a foreign-language monologic communication competence of future philologists with the consideration of certain psychological peculiarities.

It should be said that foreign language competence provides a certain cultural level of oral and written speech and non-verbal speech behavior.

Formation of a monologic communicative competence in students of higher education institutions of different directions of preparation at the present stage of development of the world community should be considered as a mandatory component of general professional training. In order to ensure the effectiveness of the process of forming a foreign-language monologic communicative competence, it is advisable to develop new methodological approaches and determine the psychological and pedagogical conditions for their implementation.

\section{REFERENCES}

1. Alkhazishvili A. A. (2000). Osnovy ovladeniya ustnoy inostrannoy rech'yu [Fundamentals of mastering oral foreign speech], p. 72-73 [in Russian].

2. Bogdanova S. S. (1988). Logiko-kommunikativnyye programmy pri obuchenii monologicheskomu vyskazyvaniyu [Logic-communicative programs in teaching monologic utterance], 5, p. 35-43 [in Russian].

3. Bukharkina M. YU. (2005). Metod proyektov $v$ obuchenii angliyskomu yazyku [The project method in teaching English]. Inostrannyye yazyki v shkole [Foreign languages at school], 3. p. $24-28$ [in Russian].

4. Canal M. (1983). From communicative competence to communicative language pedagogy. Language and Communication. (p. 2-27).

5. Hymes D. (1972). On communicate competence: Sociolinguistics. Harmondsworth, Middlesex : Penguin Education, (p. 269-293).

6. Kabardov M. K., Artsishevskaya Ye.V. (1996). Tipy yazykovykh $i$ kommunikativnykh sposobnostey $i$ kompetentsiy. [Types of linguistic and communicative abilities and competencies.], 1. (p. 34 - 49) [in Russian].

7. Leont'yev A. A. (2003). Yazyk, rech', rechevaya deyatel'nost'. [Language, speech, speech activity]. (p. 62 - 63) [in Russian].

8. Levchyk N. S., (2015). Formuvannya anhlomovnoyi audytyvnoyi kompetentnosti pershokursnykiv - maybutnikh uchyteliv anhliys'koyi movy [Formation of English-speaking auditory competence of freshmen - future English teachers]. Seriya: Pedahohichna: nauk. zapysky. Linhvodydaktyka [Series: Pedagogical: scientific notes. Linguistics.], 3. (p. 80-86) [in Ukrainian]. 
9. Martynova R.Iu. (2013). English for social teachers: navch. posibnyk dlia studentiv pedahohichnykh universytetiv. Odesa : vydavets Bukaiev Vadym Viktorovych [in Ukrainian].

10. Passov S. I. (1988). Urok inostrannogo yazyka $v$ sredney shkole [Foreign language lesson in high school], (p. 51-52) [in Russian].

11. Rogova G. V., Rabinovich F. M., Sakharova T. Ye. (2000). Metodika obucheniya inostrannomu yazyku $v$ sredney shkole. [Methods of teaching a foreign language in high school]. (p. 49 - 50) [in Russian].

12. Skalkin V. L. (1983). Obucheniye monologicheskomu vyskazyvaniyu: posobiye [dlya uchiteley] [Teaching monologic utterance: a manual [for teachers]], (p. 55) [in Russian].

13. Skalkin V. L. (1989). Obucheniye dialogicheskoy rechi. [Teaching dialogue speech.], (p. 8-10) [in Russian].

14. Sokol I. A. (2008). Proyekt kak metod realizatsii kommunikativnogo podkhoda $v$ obuchenii inostrannomu yazyku [Project as a method of implementing a communicative approach in teaching a foreign language]. Inostrannyye yazyki $v$ shkole. [Foreign languages at school], 1, (p. $16-21)$ [in Russian].

15. Symonenko T. V. (2006). Teoriia i praktyka formuvannya profesiinoi movnokomunikatyvnoi kompetentsii studentiv filolohichnykh fakultetiv. [Theory and practice of formation of professional linguistic competence of students of philological faculties.], (p. 38-40) [in Ukrainian].

16. Tal'skova N. D. (2004). Teoriya obucheniya inostrannym yazykam [Theory of teaching foreign languages], (p. $224-225$ ) [in Russian].

17. Tarnopolskyi O. B., Kozhushko S. P. (2008). Metodyka navchannya studentiv vyshchykh navchalnykh zakladiv pysma anhliyskoyu movoyu [Methods of teaching students of higher educational establishments writing in English], (p. 87-88) [in Ukrainian].

18. Tarlakovskaya Ye. A. (2009). Obucheniye studentov lingvisticheskogo vuza sposobam realizatsii funktsii vozdeystviya monologicheskoy rechi [Teaching students of a linguistic university how to implement the function of the impact of monologic speech.], (p. 23-24) [in Russian].

19. Volfovska T. O. (2001). Komunikatyvna kompetentnist molodi yak odna $z$ peredumov dosyahnennya zhyttevoi mety [Communicative competence of youth as one of the prerequisites for achieving a life goal]. Shlyakh osvity [Path of education], 3, (p. 13-16) [in Ukrainian].

20. Yakobson P. M. (1969). Problema motivatsii $v$ psikhologii povedeniya cheloveka [The problem of motivation in the psychology of human behavior] [in Russian].

21.Zadorozhna I. P. (2012). Teoretyko-metodychni zasady orhanizatsii samostiynoi roboty maybutnikh uchyteliv $z$ ovolodinnya anhlomovnoyu 
komunikatyvnoyu kompetentsiey. [Theoretical and methodological foundations of the organization of independent work of future teachers to master English-speaking communicative competence], (p. 482) [in Ukrainian].

22.Zimnyaya I. A. (2001). Lingvopsikhologiya rechevoy deyatel'nosti [Linguopsychology of speech activity], (p. 113) [in Russian].

\section{Information about the author:}

Hanna Bahrii, Candidate of Sciences in Psychology, Associate Professor of the Translation Department, National Academy of the State Border Guard Service of Ukraine named after Bohdan Khmelnytskyi 46, Shevchenko str., Khmelnytskyi, 29003, Ukraine ORCID ID: orcid.org/0000-0003-0928-2940 bahrii_82@ukr.net 